Original Research

\title{
Analysis of Factors Affecting the Mental Health Crisis of Coronavirus Disease Infection in Java Island
}

\section{Diah Priyantini, Nursalam Nursalam and Tintin Sukartin}

Faculty of Nursing, Universitas Airlangga, Surabaya, Indonesia

\section{ABSTRACT}

Introduction: Corona virus disease 2019 (COVID-19) is a health problem that remains a health emergency in the world and causes mental health crisis. The purpose of this study was to analyze the factors that influence the mental health crisis of COVID-19 infection on the island of Java.

Methods: A cross sectional study between June-July 2020 in Java Island, Indonesia with 1.218 respondents selected using convenience sampling. The independent variables were demographic, individual internal, psychological factors and the dependent was mental health crisis. Data were measured by demographic information, knowledge and attitude questionnaires, depression anxiety stress score, the brief 28-item COPE Inventory, questionnaire on problem faces and mental health crisis. Analysis of data is conducted by Chi square and multivariate logistic regression.

Results: The relation of demographic, individual internal and psychological factors were significant to mental health crisis and $\mathrm{P}<0.05$. After adjusted with logistic regression, psychological factors have more significant relation and the highest relation was found in stress level with $\mathrm{P}=0.000$ and $\mathrm{CI} 95 \%$ was $1.064-2.131$.

Conclusion: The contributing factor that has the strongest relationship with a mental health crisis is the level of stress that people experience. The biggest contribution that causes disruption of psychological conditions and mental health is psychological factors, which include levels of anxiety, stress, coping mechanisms and problems faced.
\end{abstract}

\section{ARTICLE HISTORY}

Received: January 18, 2021

Accepted: March 28, 2021

\section{KEYWORDS}

crisis; COVID-19; factors; mental health

\section{CONTACT}

Nursalam Nursalam

$\triangle$ nursalam@fkp.unair.ac.id

$\equiv$ Faculty of Nursing, Universitas

Airlangga, Surabaya, Indonesia

Cite this as: Priyantini, D., Nursalam, N., \& Sukartini, T. (2021). Analysis of Factors Affecting the Mental Health Crisis of Coronavirus Disease Infection in Java Island. Jurnal Ners, 16(1). 60-66. doi:http://dx.doi.org/10.20473/jn.v16i1.23321

\section{INTRODUCTION}

Corona virus disease 2019 (COVID-19) is a health problem that remains a health emergency in the world (WHO, 2020). Treatment due to COVID-19 has not been found and is still in the research stage, it makes COVID-19 still a concern (Hotez, Corry and Bottazzi, 2020; Huang et al., 2020), and affects to the increase in COVID-19 cases (Wang et al., 2020; W.Wu et al., 2020). The very rapid transmission increase in the number of cases has made people around the world worried about the existence of COVID-19 (Huang et al., 2020). This condition happens because of the ease by which the virus is transmitted so that individuals easily fall ill, and some are in critical condition and die (Covaci, 2020). COVID-19, which causes many people to fall ill and also has a high number of cases of death, makes people afraid (Fofana, 2020) and begin to overprotect themselves so that the virus does not spread (Covaci, 2020). Many people show excessive responses such as frequent hand washing, avoiding interactions, suspicious of each other because they are afraid of carrying the virus and discriminating against individuals and families of COVID-19 patients and cases of close contact (Carroll et al., 2020; Dymecka, Gerymski and Machnik-Czerwik, 2020; Nursalam et al., 2020).

The positive incidence of COVID-19 in the world is increasing day by day (Staden, 2020), since December 2019, which was the first-time cases were found in the City of Wuhan, China, and shows an increasing number of cases (Stoecklin et al., 2020). From December 2019 to February 2020, there were around 30 thousand cases of COVID-19, but by July 2020 the 
number of COVID-19 cases in the world had reached 16.39 million and in Indonesia it had reached 86,521 (Staden, 2020; WHO, 2020). The total number of deaths has reached 651 thousand cases and 65 thousand patients are hospitalized with critical conditions (Jung et al., 2020). The highest number of cases of COVID-19 is in Java with a proportion of $80 \%$ of the total cases in Indonesia (Nursalam et al., 2020). The high number of cases makes people show varied psychological responses, ranging from mild to severe responses (Barzilay et al., 2020; Carroll et al., 2020). Based on research conducted in China on 7,143 students, it showed that as many as $75.1 \%$ did not experience symptoms of anxiety, while the proportion of students with mild, moderate, and severe anxiety was $21.3 \%, 2.7 \%$, and $9 \%$, respectively (Cao et al., 2020; Ying Wang et al., 2020). Meanwhile, based on the research results, people in Italy showed that $31.38 \% \quad$ experienced general psychopathological symptoms, $37.19 \%$ experienced anxiety and $27.72 \%$ showed symptoms of PostTraumatic Stress Disorder (Maugeri et al., 2020; Pakenham et al., 2020). In Indonesia, the cases of physical problem showed that $60 \%$ have mild and asymptomatic symptoms, but in psychological responses showed that $75 \%$ people felt anxiety and were afraid during first wave of COVID-19 crisis. This shows that the psychological response faced by a person is also a serious problem that needs to be intervened by all sectors of the response to COVID-19 (Cao et al., 2020; Pakenham et al., 2020).

The psychological impact shown by society is very diverse (Barzilay et al., 2020; Dymecka, Gerymski and Machnik-Czerwik, 2020), many people are really afraid of COVID-19 and many also think that this virus is just a conspiracy and does not exist in the world (Georgiou, Delfabbro and Balzan, 2020). This incorrect assumption makes virus transmission more difficult to control (Fofana, 2020), because people do not want to participate in taking prevention. During the year that COVID-19 became a pandemic, public vigilance was still not $100 \%$ (16), such as washing hands (92.7\%), maintaining social distancing (92.3\%), using face masks (86.5\%) ), avoiding travel to infected areas or countries (86.9\%) and seeking correct information behavior (42.4\%). In addition, people who think that COVID-19 is a dangerous and easily transmitted virus at any time will show an exaggerated psychological response (Carroll et al., 2020; Dymecka, Gerymski and Machnik-Czerwik, 2020). The community will show excessive psychosomatic symptoms, resulting in behaviors that are repeated in implementing health protocols (Barzilay et al., 2020; Carroll et al., 2020; Dymecka, Gerymski and Machnik-Czerwik, 2020). The national health emergency that has occurred in Indonesia since March 2020 has made COVID-19 a frightening infection for the community (Fofana et al.,2020). The large number of confirmed cases and deaths due to COVID-19 have created a negative stigma to stay away from anyone who is at risk of transmitting it, health workers who are caring for it (Nursalam et al.,
2020). Patients, families of positive patients and patients who have recovered from COVID-19, including the community also rejects the patient's body because they think it can still be contagious (Hotez, Corry and Bottazzi, 2020). Inaccurate information obtained from various media makes people more anxious and excessively anxious, as a result a mental health crisis, psychological impact and community stigma also occur (Covaci, 2020; Dymecka, Gerymski and Machnik-Czerwik, 2020).

Psychological problems found in Indonesian society, including mental health crisis and stigma, must be immediately given further intervention so as not to cause more severe problems (Nursalam et al., 2020). So far, there are still many research that have been implemented in Indonesia that are physical, but psychological factors have not been given much attention, so there are still many who experience anxiety because the information obtained is also inaccurate (Dymecka, Gerymski and MachnikCzerwik, 2020). Based on previous research about COVID-19, the psychological response that causes crisis condition has not yet been greatly identified, because the pandemic condition makes people need to first adapt to the crisis. The psychological problem has certainly initiated mental health crisis, a condition that causes severe psychological problems and risk factors to mental disorder. Based on the above problems, psychological impacts need to be explored more deeply so that they can produce the most appropriate psychological interventions in dealing with psychological impacts, mental health crisis and social stigma that exist in society. The purpose of this study was to analyze the factors that influence the mental health crisis of COVID-19 infection on the island of Java.

\section{MATERIALS AND METHODS}

This research is a cross-sectional study conducted in June-July 2020 in Java Island, Indonesia. The affordable population of this study are people in the community aged 20-54 years who live in Java Island. The selection of research samples used convenience sampling techniques through online and offline media. Assessment of demographic factors, individual internal factors, psychological factors and community mental health crisis was done using a structured questionnaire. Charging is confidential to ensure confidentiality and reliability of data. The research sample was 1218 respondents spread across five provinces in Java Island, namely Jakarta, West Java, Yogyakarta, Central Java and East Java.

This study uses independent variables, namely demographic factors, individual internal factors and psychological factors. Demographic factors consist of location of residence, ethnicity, marital status, income, religion and health status. Individual internal factors consist of age, gender, level of education, knowledge and attitudes. Meanwhile, psychological factors consist of the level of stress, anxiety, coping mechanisms and the problems faced. The dependent 
variable of this study is mental health crisis. The research instrument is in the form of a structured questionnaire package which includes asking for demographic information, knowledge and attitude questionnaires from Mohammed Dauda Goni (2018), and depression anxiety stress score (Lovibond and Lovibond, 1995), the brief 28-item COPE Inventory (Carver, 1997), questionnaire on problem faced (Gilhooly et al., 2007) and mental health crisis emergencies questionnaire (Talevi et al., 2020). The entire questionnaire consisted of 5-21 questions using a Likert rating scale of 4 items ranging from 1 (Strongly disagree) to 4 (Strongly agree), so that the total score ranges from 0 to 84 . The instrument has conducted initial trials which are well-validated, and has shown a reliability value that is Cronbach's a between 0.875 to 0.995 .

Data collection started in June 2020 and online and offline questionnaire were conducted by the researchers. Research beforehand was used to conduct licensing to institutions and to take care of ethical due diligence. Offline data collection was carried out by giving questionnaires to respondents directly. Respondents filled out questionnaires by first giving informed consent without coercion. Online data collection was done via Google Forms and it was ensured that all respondents filled in voluntarily and without coercion. Respondents filled in the questions that have been written; if there were respondents who did not fill in completely, the respondent was considered to be in the drop out criteria and not counted as research respondents. The researcher then collected questionnaires that had been filled in and conducted data recapitulation for further data analysis.

Data analysis was performed using SPSS version 22.0 software to test inferential statistics, namely the Chi square test and logistic regression. Descriptive statistical analysis was conducted to describe the demographic characteristics of the respondents. Bivariate analysis (nonparametric test) with Chi square was used to explore the significant relationship between sample characteristics, individual internal factors, psychological factors and mental health crisis. Statistically significant variables were screened and included in the multivariate logistic regression analysis to identify the most dominant factor of all variables. Estimates of association strength are indicated by odds ratio (OR) with 95\% confidence interval (CI), p value is considered significant with value 0.05 .

This research has received ethical approval from the Ethics Committee of the Faculty of Nursing, Airlangga University, Indonesia and has received a certificate of ethical acceptance with the number 2038-KEPK. After being given an explanation and instructions regarding the research procedure, all respondents voluntarily gave their consent and participated in the research. This research procedure was in accordance with the provisions of the Declaration of Helsinki on Human participant research.

\section{RESULTS}

Based on the results of research conducted in JuneJuly 2020, it was found that the highest demographic characteristics of respondents were domiciled in East Java, as many as 569 respondents (46.7\%), with the majority ethnicity being Javanese, with 895 respondents $(73.5 \%)$. The majority religion was Islam as many as 1139 respondents (93.5\%). Respondents who were not married were 813 respondents $(66.7 \%)$, as many as 376 respondents $(30.9 \%)$ as students and working as nurses were 240 respondents (19.7\%). The majority of the income level is still below the Regional Minimum Wage (UMR), which is as many as 652 respondents (53.5\%). In health status, $1122(92.1 \%)$ respondents were healthy and those who were confirmed positive for COVID-19 were 59 (4.8\%) respondents (Table 1).

Table 1 describes the variables of individual internal factors, which consist of age, gender, education level, knowledge and attitudes and psychological factor variables consisting of stress levels, anxiety levels, coping mechanisms and problems faced by respondents. Based on the results of the study, it showed that the most respondents were women, as many as 841 (69.0\%) respondents, with the most dominant age range late adolescence (17-25 years) as many as 544 (44.7\%) respondents and $698(57,3 \%)$ respondents have a bachelor's level education. The level of knowledge possessed by the respondents showed that the results were mostly good at 867 (71.2\%) of respondents, while 869 (71.3) respondents had attitudes in the good category as well. The stress level of the research respondents showed that the highest result was in the normal category, although there were 143 (11.7\%) respondents who indicated that the stress category was very heavy. The level of anxiety also shows the results of $538(44.2 \%)$ respondents are in the normal category and the condition of a very high level of anxiety is found quite extensively, namely 288 $(23.6 \%)$ of respondents. For the coping mechanism shown by respondents, 906 (74.4\%) of respondents showed a high ability of the mechanism, while the problems faced by respondents were mostly in the category of moderate problems as many as 874 $(71.8 \%)$ of respondents. In the mental health crisis, $23.4 \%$ of the community showed a response to the crisis, namely the need for counseling services, mental health resolution and experiencing a mental health crisis.

Demographic characteristics of respondents have a significant relationship with the incidence of mental health crisis with all $\mathrm{P}$ values $<0.005$. Based on the location of the respondents who experienced the most mental health crisis in West Java (2.6\%), according to the request for counseling needs of the Sundanese ethnic group, this was $19.2 \%$. 11.9\% of individuals who are still single also need counseling, while $24.1 \%$ of people with a Confucian religion experience a mental health crisis. The occupations that need counseling the most are students (17.3\%) 
and entrepreneurs (21.1\%). Workers who have a source of income below the minimum regional income are also prone to mental health crisis, including people who are often exposed to COVID-19 or at high risk (16.7\%) (Table 2).

The internal factors of the individual indicate that age, level of education, knowledge and attitudes have a significant relationship with mental health crisis (all $\mathrm{P}<0.05$ ). The highest incidence rate of mental health problems was indicated by late adolescence, namely $15.4 \%$ needed mental health services, $11.0 \%$ needed counseling and $1.8 \%$ experienced a mental health crisis. Women are the respondents who experience the most mental problems, at the level of education the higher the risk of mental health crisis. Low public knowledge and attitudes also have the potential for mental health problems (Table 2).

Psychological factors are the highest predisposition for causing mental health problems, based on the $\mathrm{X}$ table of individuals with stress levels, anxiety levels, low coping mechanism abilities and facing severe problems shows a greater mental health crisis. The proportion of mental health crisis was mostly experienced by individuals with very severe stress levels $(7.7 \%)$ and low coping mechanisms (6.3\%).

In the multivariate analysis test (Table 3 ) the factors that had a significant relationship with $\mathrm{P}<0.05$ were age, location, marital status, occupation, educational background, income, knowledge, anxiety levels, stress levels and coping mechanisms. After being adjusted, multivariate analysis was performed using logistic regression with a 95\% CI showing that

Table 3. Multivariate Analysis in Mental Health Crisis Contributing Factors

\begin{tabular}{|c|c|c|c|c|}
\hline \multirow[b]{2}{*}{ Variable } & \multirow{2}{*}{$\begin{array}{c}\mathbf{P} \\
\text { Value }\end{array}$} & \multirow{2}{*}{$\begin{array}{c}\text { Odds } \\
\text { Ratio } \\
\text { (OR) }\end{array}$} & \multicolumn{2}{|c|}{ CI 95\% } \\
\hline & & & Lower & Upper \\
\hline Age & $0.004 *$ & 0.912 & 0.764 & 1.089 \\
\hline Gender & 0.177 & 1.162 & 0.784 & 1.721 \\
\hline Location & $0.000^{*}$ & 0.819 & 0.710 & 0.944 \\
\hline $\begin{array}{l}\text { Marital } \\
\text { Status }\end{array}$ & $0.000^{*}$ & 0.788 & 0.509 & 1.219 \\
\hline Ethnics & 0.933 & 1.064 & 0.918 & 1.232 \\
\hline Religion & 0.255 & 0.878 & 0.680 & 1.135 \\
\hline Occupation & $0.008^{*}$ & 1.041 & 0.978 & 1.108 \\
\hline $\begin{array}{l}\text { Educational } \\
\text { Background }\end{array}$ & $0.000^{*}$ & 1.082 & 0.895 & 1.307 \\
\hline Income & $0.005^{*}$ & 0.825 & 0.559 & 1.217 \\
\hline $\begin{array}{l}\text { COVID-19 } \\
\text { Status }\end{array}$ & 0.974 & 0.939 & 0.753 & 1.170 \\
\hline Knowledge & $0.001^{*}$ & 0.578 & 0.396 & 0.843 \\
\hline Attitude & 0.238 & 0.494 & 0.347 & 0.702 \\
\hline $\begin{array}{l}\text { Anxiety } \\
\text { Level }\end{array}$ & $0.000^{*}$ & 0.756 & 0.540 & 1.058 \\
\hline Stress Level & $0.000^{*}$ & 1.506 & 1.064 & 2.131 \\
\hline $\begin{array}{l}\text { Coping } \\
\text { Mechanism }\end{array}$ & $0.000^{*}$ & 0.297 & 0.177 & 0.498 \\
\hline $\begin{array}{l}\text { Problem } \\
\text { Faced }\end{array}$ & 0.869 & 1.131 & 0.755 & 1.693 \\
\hline
\end{tabular}

* Significant Relation $\mathrm{P}<0.05$ the factor that had the highest association with mental health crisis was stress level $(\mathrm{P}=0.000)$ with CI between 1.064 and 2.131, It shows that stress level influenced mental health crisis more than other factors.

\section{DISCUSSION}

Psychological factors are closely related to the causes of mental health crisis, especially the level of stress experienced by individuals (Wu et al., 2020). The important finding of this research was stress level has highest relation with mental health crisis, and some variables, like age, location, marital status, occupation, educational background, income, knowledge, anxiety levels, stress levels and coping mechanisms, too. Significant relation of the results finding indicated that crisis condition has many contributing factors. Based on the research results, data show the level of stress from the community due to the COVID-19 pandemic, which shows the severe and very severe categories are still very high. This is in accordance with research conducted in the U.S., Israel and several other countries showing that the level of stress due to the COVID-19 pandemic is very high in all countries in the world. The results showed that the stress experienced by the community was due to: 1) fear of being infected; 2) many cases of people who died from COVID-19 infection; 3) the situation in the environment is not conducive and the whole community uses masks, suspect each other and always keep their distance; 4) the presence of an infected family member and close contact; 5) asymptomatic positive cases that unknowingly infected others; and 6) the resulting economic impact, causing financial distress (Barzilay et al., 2020; Carroll et al., 2020). The cause which is the main triggering factor is that the information and knowledge received by the community is not quite right. This is also in line with research (Georgiou, Delfabbro and Balzan, 2020) which states that the public believes more in conspiracy theories, so that they think that COVID-19 is just a lie. The behavior of the people who think that COVID-19 does not exist has ultimately made the spike in cases increase (Qiu et al., 2020). As a result, $60 \%$ of health workers showed moderate and severe stress responses in one study in China. What makes them stressed is that health workers are ready to be at the forefront, but people do not want to participate positively in joint prevention, so health workers are exhausted because they have to use personal protective equipment every day (WHO, 2020).

Demographic factors also have an impact on the incidence of mental health crisis. The older or younger people have higher response to crisis than optimal age. Females also have higher risk factors for crisis because they always feel very sad whenever they have some problems. The level of education indicated that higher education makes coping mechanism to stress better than less education, likewise those with higher knowledge also have 
better response to crisis (Giallonardo et al., 2020), the effects of self-quarantine and social restrictions also cause fear (Dymecka, Gerymski and MachnikCzerwik, 2020). The results show that mental health crises are prevalent in locations with the most cases of COVID-19 and large-scale social distancing, such as Jakarta (59.7\%). Jakarta is the highest location with mental health crisis because of the highest cases and small size of area, so the COVID-19 transmission is fast. A pandemic also hampers various sectors of the economy and education, thus making students and entrepreneurs vulnerable to stress levels and some need counseling (Bonaccorsi et al., 2020; König, Jägerbiela and Glutsch, 2020). This is in line with research conducted in China, where many students experience delays in graduation due to digital adaptation and cannot immediately get a job after graduating (Fernandes, 2020; König, Jäger-biela and Glutsch, 2020). Meanwhile, entrepreneurs experience a financial crisis due to their business being quiet and then closed, unlike entrepreneurs who sell products needed during a pandemic (Ashraf, 2020; Bonaccorsi et al., 2020). Community income tends to decline due to COVID-19 because many are dismissed and work from home, employees then experience burnout and eventually fall into a state of mental health crisis (Zar et al., 2020).

Internal factors of the individual show that age, level of education, knowledge and attitudes are also the cause of the emergence of a mental health crisis (Nursalam et al., 2020). Mental health crises are more likely to occur in vulnerable groups, such as young people, the elderly and women. Some groups with low levels of education and knowledge also have a higher risk. This high risk is caused by insufficient information that can be explored properly, resulting in confusion and fear. Based on research conducted in several countries, it shows that negative responses occur in many groups of people who are too young and too old, because they are not ready for the changes that occur (Boulle et al., no date; Nepomuceno et al., 2020). The level of education also has an effect, people with higher education tend to be easier to provide health education than people who think that conspiracy is the cause of COVID-19 (Georgiou, Delfabbro and Balzan, 2020; Nepomuceno et al., 2020). However, difficulties are experienced by people who are very ignorant of the situation, they do not want to contribute to breaking the chain of transmission (Nursalam et al., 2020). The knowledge and attitudes of the community also show much variation, there are people who are very obedient and obedient to health protocols, there are others who only do so sometimes and some do not care at all. I is very important for health workers to take a promotive and preventive approach (Williamson et al., 2020; Wu et al., 2020; Yenan Wang et al., 2020).

Psychology from society also plays an important role in controlling mental health problems, the level of public anxiety due to the information that is widely circulating raises anxiety and fear, a lot of information is invalid and only makes the situation worse (Boulle et al., no date; Dymecka, Gerymski and MachnikCzerwik, 2020). As a result, the community stigmatizes individuals who are positive for COVID19, including their families, and refuses health workers to return home (Bagcchi, 2020; Ramaci et al., 2020). The coping mechanisms shown by health workers are still adaptive; however, many people are saddened to overdo it because family members died of COVID-19 and were buried using strict procedures (Benussi et al., 2020). In addition, many exhibit psychosomatic symptoms and fear of their own psychological problems, which are the main cause of mental health crisis, and which need attention so that they do not get worse.

The limitation of this study is the need to pay attention to several other factors that may have the effect of causing a mental health emergency crisis, including external or environmental factors. The study was conducted by using convenience sampling, so that the sample needed to represent the national level is multicenter. This research was conducted at a time when the crisis conditions due to COVID-19 were very high, so that in the last months of the year it started to return to normal, so that psychological and mental health problems began to adapt to the pandemic. However, this research is strong enough to detect significant impacts, using validated instruments with validity and reliability values according to standards.

\section{CONCLUSION}

The contributing factor that has the strongest relationship with a mental health crisis is the level of stress that people experience. The biggest contribution that causes disruption of psychological conditions and mental health is psychological factors, which include levels of anxiety, stress, coping mechanisms and problems faced; these four factors can become precipitative in the COVID-19 pandemic, so it is necessary to give psychological treatment as a form of preparedness.

\section{ACKNOWLEDGMENT}

We would like to thank all participants who were willing to fill in the research data. This research is a study that has received grant support from the Institute for Research and Innovation, Universitas Airlangga in the form of COVID-19 Mandate Research. Organizations that provide funding contribute to monitoring the implementation of research and researchers carry out research in accordance with the research method that has been conceptualized, so that research publications will be produced as outputs to be reported.

\section{REFERENCES}

Ashraf, B. N. (2020). Journal of Behavioral and Experimental Finance Economic impact of government interventions during the COVID-19 pandemic: International evidence from financial 
markets. Journal of Behavioral and Experimental Finance, 27, 100371. https://doi.org/10.1016/j.jbef.2020.100371

Bagcchi, S. (2020). Stigma during the COVID-19 pandemic. The Lancet. Infectious Diseases. https://doi.org/10.1016/S1473-3099(20)304989

Barzilay, R., Moore, T. M., Greenberg, D. M., DiDomenico, G. E., Brown, L. A., White, L. K., Gur, R. C., \& Gur, R. E. (2020). Resilience, COVID-19related stress, anxiety and depression during the pandemic in a large population enriched for healthcare providers. Translational Psychiatry, 10(1). https://doi.org/10.1038/s41398-02000982-4

Benussi, A., Pilotto, A., Premi, E., Libri, I., Giunta, M., Agosti, C., Alberici, A., Baldelli, E., Benini, M., Bonacina, S., Brambilla, L., Caratozzolo, S., Cortinovis, M., Costa, A., Cotti Piccinelli, S., Cottini, E., Cristillo, V., Delrio, I., Filosto, M., ... Padovani, A. (2020). Clinical characteristics and outcomes of inpatients with neurologic disease and COVID-19 in Brescia, Lombardy, Italy. Neurology. https://doi.org/10.1212/WNL.00000000000098 48

Bonaccorsi, G., Pierri, F., Cinelli, M., Flori, A., Galeazzi, A., Porcelli, F., Schmidt, A. L., Valensise, C. M., Scala, A., Quattrociocchi, W., \& Pammolli, F. (2020). Economic and social consequences of human mobility restrictions under COVID-19. Proceedings of the National Academy of Sciences of the United States of America, 117(27), 15530-15535. https://doi.org/10.1073/pnas.2007658117

Boulle, A. A., Davies, M., Hussey, H., Morden, E., Vundle, Z., Zweigenthal, V., Mahomed, H., Paleker, M., Pienaar, D., Tembo, Y., Lawrence, C., Mathema, H., Allen, D., Allie, T., Bam, J., Dane, P., Heekes, A., Matlapeng, B., Muzarabani, L., ... Pienaar, R. (n.d.). Risk factors for COVID-19 death in a population cohort study from the Western Cape Province, South Africa. 1-31.

Cao, W., Fang, Z., Hou, G., Han, M., Xu, X., \& Dong, J. (2020). The psychological impact of the COVID-19 epidemic on college students in China. Psychiatry Research, 287(March), 112934. https://doi.org/10.1016/j.psychres.2020.112934

Carroll, N., Sadowski, A., Laila, A., Hruska, V., Nixon, M., Ma, D. W. L., \& Haines, J. (2020). The impact of covid-19 on health behavior, stress, financial and food security among middle to high income canadian families with young children. Nutrients, 12(8), $1-14$. https://doi.org/10.3390/nu12082352

Carver, C. S. (1997). Brief COPE Inventory. International Journal of Behavioral Medicine.

Covaci, A. (2020). How can airborne transmission of COVID-19 indoors be minimised? Environment International, 142(May), 1-7. https://doi.org/10.1016/j.envint.2020.105832

Dymecka, J., Gerymski, R., \& Machnik-Czerwik, A. (2020). How does stress affect our life satisfaction during COVID-19 pandemic? Moderated mediation analysis of sense of coherence and fear of coronavirus. https://doi.org/10.31234/osf.io/3zjrx

Fernandes, N. (2020). Economic effects of coronavirus outbreak ( COVID-19) on the world economy Nuno Fernandes Full Professor of Finance IESE Business School Spain. SSRN Electronic Journal, ISSN 1556-5068, Elsevier BV, 029.

Fofana, Nina-Kandiatou, Latif, Faiza, Sarfraz, Summaira, Bilal, Bilal, Bashir, Muhammad Farhan, Komal, B. (2020). Fear and agony of the pandemic leading to stress and mental illness: An emerging crisis in the novel coronavirus (COVID-19) outbreak. Psychiatry Research, 291(April), 9-11. https://doi.org/10.1016/j.psychres.2020.113230

Georgiou, N., Delfabbro, P., \& Balzan, R. (2020). Personality and Individual Di ff erences COVID-19related conspiracy beliefs and their relationship with perceived stress and pre-existing conspiracy beliefs. Personality and Individual Differences, 166(April), 110201. https://doi.org/10.1016/j.paid.2020.110201

Giallonardo, V., Sampogna, G., Vecchio, V. Del, Luciano, M., Albert, U., Carmassi, C., Carrà, G., Cirulli, F., Osso, B. D., Nanni, M. G., Pompili, M., \& Sani, G. (2020). The Impact of Quarantine and Physical Distancing Following COVID-19 on Mental Health : Study Protocol of a Multicentric Italian Population Trial. 11(June), 1-10. https://doi.org/10.3389/fpsyt.2020.00533

Gilhooly, M. L., Gilhooly, K. J., Phillips, L. H., Harvey, D., Brady, A., \& Hanlon, P. (2007). Real-world problem solving and quality of life in older people. British Journal of Health Psychology. https://doi.org/10.1348/135910706X154477

Hotez, P. J., Corry, D. B., \& Bottazzi, M. E. (2020). COVID-19 vaccine design: the Janus face of immune enhancement. Nature Reviews Immunology, 20(June), 347-348. https://doi.org/10.1038/s41577-020-0323-4

Huang, L., Rong, Y., Pan, Q., Yi, K., \& Tang, X. (2020). SARS-CoV-2 vaccine research and development: conventional Corresponding author . Clinical Trial Center of Zhongnan Hospital, Wuhan. Asian Journal of Pharmaceutical Sciences. https://doi.org/10.1016/j.ajps.2020.08.001

Jung, S., Akhmetzhanov, A. R., Hayashi, K., Linton, N. M., Yang, Y., Yuan, B., Kobayashi, T., Kinoshita, R., \& Nishiura, H. (2020). Real-Time Estimation of the Risk of Death from Novel Coronavirus (COVID-19) Infection: Inference Using Exported Cases. Journal of Clinical Medicine, 9(2), 523. https://doi.org/10.3390/jcm9020523

König, J., Jäger-biela, D. J., \& Glutsch, N. (2020). Adapting to online teaching during COVID-19 school closure: teacher education and teacher competence effects among early career teachers in Germany. European Journal of Teacher Education, 43(4), 608-622. https://doi.org/10.1080/02619768.2020.18096 50 
Lovibond, S. H., \& Lovibond, P. F. (1995). Manual for the Depression Anxiety Stress Scales. In Psychology Foundation of Australia.

Maugeri, G., Castrogiovanni, P., Battaglia, G., Pippi, R., Agata, V. D., Palma, A., Di, M., \& Musumeci, G. (2020). Heliyon The impact of physical activity on psychological health during Covid-19 pandemic in Italy. Heliyon, 6(May), e04315. https://doi.org/10.1016/j.heliyon.2020.e04315

Nepomuceno, M. R., Acosta, E., Alburez-Gutierrez, D., Aburtod, J. M., Aburtod, J. M., Gagnon, A., Gagnon, A., \& Turra, C. M. (2020). Besides population age structure, health and other demographic factors can contribute to understanding the COVID-19 burden. Proceedings of the National Academy of Sciences of the United States of America, 117(25), 13881-13883. https://doi.org/10.1073/pnas.2008760117

Nursalam, N., Sukartini, T., Priyantini, D., Mafula, D., Efendi, F., \& Airlangga, U. (2020). RISK FACTORS FOR PSYCHOLOGICAL IMPACT AND SOCIAL STIGMA AMONG PEOPLE FACING COVID-19: A. Systematic Reviews in Pharmacy, 11(6), 10221028.

Pakenham, K. I., Landi, G., Boccolini, G., Furlani, A., Grandi, S., \& Tossani, E. (2020). Journal of Contextual Behavioral Science The moderating roles of psychological flexibility and inflexibility on the mental health impacts of COVID-19 pandemic and lockdown in Italy. Journal of Contextual Behavioral Science, 17(July), 109-118. https://doi.org/10.1016/j.jcbs.2020.07.003

Qiu, J., Shen, B., Zhao, M., Wang, Z., Xie, B., \& Xu, Y. (2020). A nationwide survey of psychological distress among Chinese people in the COVID-19 epidemic: Implications and policy recommendations. In General Psychiatry. https://doi.org/10.1136/gpsych-2020-100213

Ramaci, T., Barattucci, M., Ledda, C., \& Rapisarda, V. (2020). Social stigma during COVID-19 and its impact on HCWs outcomes. Sustainability (Switzerland). https://doi.org/10.3390/su12093834

Staden, C. Van. (2020). COVID-19 and the crisis of national development. Nature Human Behaviour, 4(May), 443-444. https://doi.org/10.1038/s41562-020-0852-7

Stoecklin, S. B., Rolland, P., Silue, Y., Mailles, A., Campese, C., Simondon, A., Mechain, M., Meurice, L., Nguyen, M., Bassi, C., Yamani, E., Behillil, S., \& Ismael, S. (2020). First cases of coronavirus disease 2019 ( COVID-19) in France : surveillance , investigations and control measures, January 2020. Eurosurveillance, 25(6). https://doi.org/10.2807/15607917.ES.2020.25.6.2000094

Talevi, D., Socci, V., Carai, M., Carnaghi, G., Faleri, S., Trebbi, E., Bernardo, A. D. I., Capelli, F., \& Pacitti, F.
(2020). Mental health outcomes of the covid-19 pandemic. Rivista Di Psichiatria. https://doi.org/10.1708/3382.33569

Wang, H., Liu, Y., Hu, K., Zhang, M., \& Du, M. (2020). Healthcare workers 'stress when caring for COVID19 patients: An altruistic perspective. 27(1095), 1490-1500. https://doi.org/10.1177/0969733020934146

Wang, Yenan, Di, Y., Ye, J., \& Wei, W. (2020). Study on the public psychological states and its related factors during the outbreak of coronavirus disease 2019 (COVID-19) in some regions of China. Psychology, Health and Medicine, 8506. https://doi.org/10.1080/13548506.2020.17468 17

Wang, Ying, Ma, S., Yang, C., Cai, Z., Hu, S., Zhang, B., Tang, S., Bai, H., Guo, X., Wu, J., Du, H., Kang, L., Tan, H., Li, R., Yao, L., \& Wang, G. (2020). Acute psychological effects of Coronavirus Disease 2019 outbreak among healthcare workers in China : a cross-sectional study. Translational Psychiatry. https://doi.org/10.1038/s41398-020-01031-w

WHO. (2020). Novel Coronavirus 2020 (3) (Issue JANUARY, pp. 1-7). https://www.pio.gov.cy/coronavirus/pdf/8_1_od hgies_plhroma_asthenophoron.pdf

Williamson, E. J., Walker, A. J., Bhaskaran, K., Bacon, S., Bates, C., Morton, C. E., Curtis, H. J., Mehrkar, A., Evans, D., Inglesby, P., Cockburn, J., McDonald, H. I., MacKenna, B., Tomlinson, L., Douglas, I. J., Rentsch, C. T., Mathur, R., Wong, A. Y. S., Grieve, R., ... Goldacre, B. (2020). Factors associated with COVID-19-related death using OpenSAFELY. Nature, 584(7821), 430-436. https://doi.org/10.1038/s41586-020-2521-4

Wu, C., Chen, X., Cai, Y., Xia, J., Zhou, X., Xu, S., Huang, H., Zhang, L., Zhou, X., Du, C., Zhang, Y., Song, J., Wang, S., Chao, Y., Yang, Z., Xu, J., Zhou, X., Chen, D., Xiong, W., ... Song, Y. (2020). Risk Factors Associated with Acute Respiratory Distress Syndrome and Death in Patients with Coronavirus Disease 2019 Pneumonia in Wuhan, China. JAMA Internal Medicine, 180(7), 934-943. https://doi.org/10.1001/jamainternmed.2020.0 994

Wu, W., Zhang, Y., Wang, P., Zhang, L., Wang, G., Lei, G., Xiao, Q., Cao, X., Bian, Y., Xie, S., Huang, F., Luo, N., Zhang, J., \& Luo, M. (2020). Psychological stress of medical staffs during outbreak of COVID-19 and adjustment strategy. Journal of Medical Virology. https://doi.org/10.1002/jmv.25914

Zar, H. J., Dawa, J., Bueno, G., \& Castro-rodriguez, J. A. (2020). Challenges of COVID-19 in children in lowand middle-income countries. Paediatric Respiratory Reviews, 35, 70-74. https://doi.org/10.1016/j.prrv.2020.06.016 